\title{
A Nexus among Reliability Improvement of Distribution System with Optimal Placement and Capacity of Wind-Based Distributed Generation Management
}

\author{
Syahrial Shaddiq ${ }^{1 *}$, Agustian Ramadana Putera ${ }^{2}$, Lisda Aisyah ${ }^{3}$, \\ Misnasanti $^{4}$, Ainun Mahfuzah $^{5}$ \\ ${ }^{1}$ Universitas Cahaya Bangsa (yoUCB), Indonesia \\ 2,4,5 Universitas Negeri Yogyakarta (UNY), Indonesia \\ ${ }^{3}$ STAI Darul Ulum Kandangan, Indonesia \\ *Corresponding author, e-mail: syahrialcyber@gmail.com
}

\begin{abstract}
Along with the world population growth, the need for a source of electrical energy is higher, so a reliable system with higher capacities is expected. Renewable energy becomes an alternative that supports the goal of reducing the risk of disruption, thus increasing the distribution system's reliability. A lot of industries and public settlement uses renewable sources of energy as an alternative power supply to comply their energy needs. This research uses wind turbine as a source of renewable energy in the distributed generation $(D G)$. However, the required investment in wind-based DG is commonly considered too costly to deploy and require a proper planning on its placement method. The flower pollination algorithm (FPA) method could be a solution to achieve optimal placement of wind-based DG, thus increase the distribution system's reliability, which is indicated by minimum energy not supplied (ENS) index.
\end{abstract}

Keywords — wind-based DG, reliability, FPA, distribution sysem, ENS.

\subsection{Research Background}

\section{INTRODUCTION}

Along with the development of the world's population, the demand for electric energy sources so that the higher the required higher power capacity. Therefore, the necessary planning of power system to generate electricity is a good and reliable [1].

The addition of power generation with renewable energies into a new alternative for reducing the risk of interference and increase the reliability of the distribution system [2]. There have been many industries that use renewable energy sources as one of the alternative sources of energy needs. Renewable energy-based power plants are generally placed on distribution system known as renewable distributed generation.

Wind power plant is one of the examples of plants scattered or distributed generation (DG) sourced on renewable energy. Such power plants can be one of the alternatives to improve reliability in the distribution system with the proper of placement [2] [3]. DG has a lot of advantages, namely increasing the reserve capacity of the main power, reducing loss-power loss in electrical flow, and can correct the voltage profile.

Generating scattered wind-based, also known as wind-based DG. Wind-based DG has advantages can reduce operational costs at the time of a peak load and improve reliability in the distribution system [3] [4] [5]. However, in research [5] [6] [7] [8] has not analysed whether the installation of a wind-based DG on distribution system will affect the improvement of the reliability of the distribution system or vice versa.

Reliability is the ability of a system to transmit electrical energy to all the users with the number and standard of acceptable or appropriate. System reliability after wind-based DG is placed on the right bus became a common goal and be considered given the factors of renewable energy investments that cannot be counted or cheap [9]. Energy not supplied (ENS) is a reliability index commonly used in the study of reliability. ENS is energy that does not supplied to load in a certain span of time. With the placement of wind-based DG, the energy supply is not supplied in the distribution system will be minimised [10] [11]. Nowadays, the placement of plants spread, especially wind-based DG into consideration given the costs of investment and maintenance costly. In addition, the placement of wind-based DG can minimise the cost of proper when the power loss occurred and when an ENS [12].

The metaheuristic method is a common method used to find the optimal placement and capacity wind-based DG when wind-based DG will be installed in the distribution system. The methods used in previous research is a method of fuzzy c-means and genetic algorithm (GA) method [12].

In previous research results that was obtained when the placement of wind-based DG conducted on distribution system by making use of the metaheuristic method, the index decreased significantly ENS [12]. In addition, the results of which have been obtained there is a gap which indicated that the result index ENS obtained could be lowered again with a better method. 
The metaheuristic method is now evolving to a mature stage. Flower pollination algorithm (FPA) is the pollination algorithm created by Xin-She Yang [13]. FPA is an efficient method with better results because it has a convergent speed higher than GA method and particle swarm optimisation (PSO) [14].

From the above problems and research gap, a method is needed for proper placement and capacity windbased DG in order to work better in the distribution system. The method that is expected to increase the reliability of the significant marked by a decline in index ENS in more significant on the distribution system.

\subsection{Formulation of the Problem}

Problems of research are as follows:

1. Where the optimal location and the optimal sizing (capacity) of wind-based DG, to increase reliability, minimise power loss, and improve voltage profile, with the right methods, on the distribution system.

2. How much is the total cost includes the cost of the investment, the maintenance costs, the cost of power loss, and cost optimisation of placement of the ENS and the capacity of wind-based DG with appropriate methods on the distribution system.

\subsection{Authenticity of Research}

Distributed generation are divided into two categories, namely generating scattered or distributed generation (DG) based renewable energy and distributed generation dispersed are not renewable energy. Distributed generation based renewable energy, such as wind-based DG, photovoltaics (PV), micro hydro, it is safer to use because it does not negatively impact due to eco-friendly [15].

Research about the optimal placement of DG has been widely developed. Placement of DG generally performed on distribution system taking into account the increase in the reliability of the distribution system [10]. Research by utilising the method of particle swarm optimisation (PSO) and neural network (NN) to improve reliability in the distribution system with the optimum placement of DG. Improvement of the reliability of the distribution system characterised by declining index ENS as has been demonstrated by researchers [10].

Research about improvement of the reliability in the distribution system characterised by a decline in the index to ENS [11]. On research [11] the decline in the index ENS in the distribution system is directly proportional to the increase in the reliability of the distribution system, as evidenced in the results of the research [11].

Nature-inspired algorithm is the FPA for the global optimisation. Xin-She Yang who was the inventor of the method of FPA [13]. Researcher compared the methods of the FPA to other methods, such as the PSO and GA from the results of a comparison of the researcher, the method gives results which turned out FPA is better than other methods. The research of using multi-objective flower pollination for optimisation. This method based metaheurusitic approach by speeding up the process of optimisation such as has been demonstrated by researchers carried out [13]. It is characterised by increasingly in short time the convergence of object in achieving fitness.

The multi-objective approach by metaheuristic and flower pollination for optimisation with multiobject proved to be working well. Optimisation with multi-object successfully conducted by researcher [14][46-50]. Approach by introducing plants scattered in more depth and fundamentally has been done by researcher [15]. The study describes the definitions, characteristics, and the principle of distributed genraion.

Research of power plant systems that utilise wind energy with optimal placement wind-based DG load configuration from the plant. The results obtained in the study indicates that plant placed with optimum will impact positively on the distribution system. The impact is seen with the increased reliability of the distribution system, as has been done by researcher [6].

Approach by utilising the method of genetic algorithm (GA) and fuzzy c-means (FCM) to increase the reliability of the distribution system is realised with optimal placement of wind-based DG. Reliability improvement in the distribution system is characterised by a decrease in the value of energy not supplied (ENS) and the value of the power loss. Such results have been proved by researcher [12].

In previous research has done research about decreasing index ENS with metaheuristic method, but it has not lowered the index ENS significantly. Subject costs also haven't peeled in research [12]. In fact, the problem of financing also be aspects that need to be examined. Thus, the author intends to examine the decline of the index ENS taking into considering the subject of the financing and anything else that has not been discussed in the review [12]. In this research, the author would like to propose an optimal placement of research with a single wind-based DG and multi wind-based DG by utilising the nature-inspired algorithm, namely FPA on IEEE 33-bus test system. On this research will be used in generating windbased DG sourced from renewable energy in order to be friendly to the environment. Optimal placement on a single wind-based DG and multi wind-based DG with FPA method is expected to be one of the solutions to improve the reliability in the distribution system. To know the performance of FPA, the 
proposed method will be compared with other optimisation methods. In addition, the capacity of windbased DG which is mounted on a bus that was selected will partake are taken into calcuated.

\subsection{Reseacrh Objectives}

The writing of this research aims to:

1. Find out about optimal placement and sizing of wind-based DG to improve reliability, minimise power loss, and improve voltage profile with the appropriate method in the distribution system.

2. In addition, the writing is also aiming to find out the cost of the investment, the maintenance costs, the cost of power loss, and cost optimisation of placement of the ENS and the capacity of wind-based DG with appropriate methods in the distribution system.

\subsection{Benefits of Research}

Writing a research is beneficial to add to the reference relating to the matter of optimal placement and capacity wind-based DG with the right method for the sake of system reliability distribution with two parameters, namely the decrease ENS and power loss. The other benefit is to add references to subject economic technique that consists of the calculation of the total cost after the optimal placement and capacity wind-based DG in the distribution system.

\section{LITERATURE REVIEW \& THEORETICAL FOUNDATIONS}

\subsection{Literature Review}

Distributed generation (DG) is a source of electrical energy which is connected directly to the distribution system [15].

Based on this capacity is divided into four categories:

a. micro distributed generation: 1 watt $<5 \mathrm{~kW}$,

b. small distributed generation: $5 \mathrm{~kW}<5 \mathrm{MW}$,

c. medium distributed generation: $5 \mathrm{MW}<50 \mathrm{MW}$, and

d. large distributed generation: $50 \mathrm{MW}<300 \mathrm{MW}$.

Based on the technology, DG is divided into three categories:

a. renewable distributed generation,

b. modular distributed generation, and

c. combined production of heat and power (CHP) distributed generation.

DG technologies, based on the source of energy, can be divided into two types, namely DG with renewable sources of energy and DG with a source of energy is not renewable. That includes renewable DG technology is wind energy [6] [8] [18], geothermal, waves, Sun, light, and others. That includes no renewable DG technology is internal combustion combustion turbine, the turbine on the micro fuel cell, machine, ice, and a combined cycle. Most sources of energy DG is designed to use green energy are assumed to be pollution-free [19].

Installation of a DG in the last few years has experienced an increase both in terms of the number of kapasitanya or spread across the world. The increase was caused by the development of system generation and an increase in promotions helped the utilisation of renewable energy sources. DG giving effect on the flow of power from a system that is associated in the distribution system. Therefore, the power loss on the system will also be influenced [20].

DG on distribution system works for a variety of purposes: improve voltage profile on feeder, reducing power loss, and increase the maximum amount of power being supplied to the cable and transformer [21]. Wind-based DG used in earlier literature review is a wind-based DG developed from a model wind turbine-driven horizontal axis wind turbine (HAWT) [6] [7] [22] [23] [24]. Wind-based DG operated at a time when the process of islanding and after the voltage and frequency are regulated so as not to endanger the system. When the voltage and frequency on the wind-based DG and distribution system already the same, then wind-based DG operated [6] [8] [18] [22].

The following things need to be thorough.

\section{1) Determinant of Placement Wind-based DG}

Measures the exact placement on DG, is as follows. Overall location calculated by various characteristics of the wind-based DG. Instead, the power loss, ENS, total cost, and voltage profile are calculated by finding the optimal capacity for each case [12].

2) Reliability

A simple way to model the wind-based DG done by providing constant value on the active power injections that are independent of the system voltage at the bus terminal. From model-based DG [2] [3] [4] [6] [8] [18] from negative load can have a positive impact for system reliability evaluation model 
could possibly if considering the limitations and capacity when recovery after disturbance. Other ways that can be done with the model units of wind-based DG [6] [8] [18] as a source of voltage controller, while the terminal voltage is maintained at a fixed value (constant) with reactive power injection. The purpose of this research on optimisation with regard to the reliability of the DG [11] [12]. That purpose is relevant to these unit wind-based DG which can have a positive impact on distribution system [6] $[8]$.

Cases that often occur with use of the DG looks at the emergence of the disorder on the main supply when wind-based DG is being operated in parallel with the system. New considerations need to be introduced, both in relation to operating procedures and the planning in the distribution system [2] [3] [18].

On research [25] [26] [27] has been developed further subject modeling wind-based DG accordingly. The system will be developed in this research by considering a variety of factors. The one most important factor in the research that has been done with regards to how the application of a certain method can placed single and multi wind-based DG appropriately. For the purposes of this study, it is also considering the development of a model of wind-based DG is the right to be placed on a distribution system, as well as variable influences in increases the reliability in the distribution system.

\subsection{Theoretical Foundations}

\subsubsection{Distributed Generation}

Distributed generation is spread or better known as distributed generation (DG) is a plant that is commonly installed close to the load. The reason DG installed close to the loads generally to improve reliability. For example, if there is disruption on the supplied not have an impact on electrical energy, DG will help supplied electrical energy to the load [28]. In addition, the DG is also beneficial to reduce power loss [23] and others.

DG sourced on renewable energies into an alternative solution because of the technology that is environmentally friendly. Wind-based DG is an example of the utilisation of renewable energy-based wind resource. Wind-based DG is implemented in the distribution system. The proper placement for wind-based DG will be beneficial in increasing the reliability index sags with ENS [29].

\subsubsection{Placement of $D G$}

Placement of DG, in particular wind-based DG is very important to do. The placement of wind-based DG proper will be effect on increasing the reliability index. When wind-based DG placed immediately near the load that affected by the disruption, by wind-based energy supply power to the DG load interference will effectiveness [10].

It will have an impact on the reliability of the index improvement was marked with index ENS. In this case, the index ENS will decrease because of the influence the placement of wind-based DG. If wind-based DG wasn't installed, index ENS will be great because no supplied electrical energy to the load over a given period. The impact on the state of the unreliable system due to the absence of supporting grid generator when there is a disturbance [11].

\subsubsection{Minimisation of ENS and Total Cost}

Maximisation of reliability in research subject is closely related with minimisation ENS. ENS minimisation is obtained by way of wind-based DG that is ready to supply electric energy on a burden that affected disorder when occurring disorders on a particular channel [25].

Before and after the placement of wind-based DG certainly changes the index of reliability. Before the placement of wind-based DG, reliability index ENS will decrease because the energy to the load supplied not affected by the disorder. Conversely, when wind-based DG has been placed correctly, it will be effect on the rise in the index of reliability. The rise in the index was marked by reliability index sags ENS [26].

In order to work and minimise ENS optimally, the placement of wind-based DG to be precise. In that connection, the objective function minimisation ENS, while constraint is a mathematical constraint functions [10] [12]. Objective function output is increased reliability. The increase was represented with minimisation index ENS. Steps to obtain index ENS is the follows [10].

1) Generating Initial Particle

On generating initial particle there is an input to the pollinators, i.e. the power is on. One input that pollinators must satisfy the constraint equation (2-1) on the following:

$$
\mathrm{P}_{\mathrm{DG}}{ }^{\mathrm{min}} \leq \mathrm{P}_{\mathrm{DG}} \leq \mathrm{P}_{\mathrm{DG}}^{\max }
$$


By fulfilling that constraint, the initials of the pollinators are generated. After acquiring the initials pollinators, the next step is to calculate the value of the objective function.

2) Objective Function

Objective function minimisation is the ENS index, whereas the function of evaluation is the application of the initials of pollination. Parameters of reliability considering minimisation ENS [10] [12]. The calculation finished using ENS minimisation equation (2-2).

Objective Function:

$\mathrm{ENS}=\sum_{\mathrm{i}=1}^{\mathrm{N}} \operatorname{Lavg}(\mathrm{i}) . \mathrm{Ui}$

ENS is energy that does not supplied to consumers (load); $\mathrm{L}_{\mathrm{avg}}$ (i) is the average of the load connected on the point $\mathrm{i}$; $\mathrm{U}_{\mathrm{i}}$ (unavailability) is not supplied electric energy due to disruption at the point $i$. After the ENS are known, then the review went into objective function to find the total cost of the investment costs, maintenance, power loss, and minimum ENS. Its calculations using the following equation (2-3).

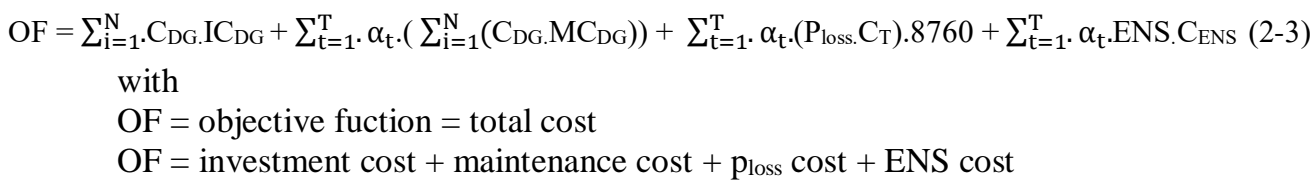

3) Updating Initial Particle

Updating the initial particle means updating the initials of pollinators. After updating the pollinators, the next step is the cessation of operations.

4) Termination

In the operations of disconnection, pollinators, i.e. best pollinators with ENS index minimum and total minimum fee was chosen as the solution. Maximisation reliability will be obtained with the placement of the optimal wind-based DG [6] [8] [18]. By placing a wind-based DG on site based on identification methods of FPA, the expected index ENS will decrease while increasing the reliability index.

\section{METHODOLOGY}

\subsection{Tools and Research Materials}

As for the tools and materials used to run the research is as follows:

1. Hardware

1) Laptop Axioo Neon HNM Model, Intel Core i7 CPU 2.0 GHz, RAM 6 GB.

2) Smartphone Lenovo A706, Quad Core Qualcomm Snapdragon 1.21 GHz, RAM $1 \mathrm{~GB}$.

2. Software

1) MATLAB 2009, Visio 2013, dan CorelDRAW X5.

2) Microsoft Office 2016.

3. Previous research data related to the improvement of reliability of utilising wind-based DG as a source of reference.

\subsection{Research Methods}

The following are the methods used in this research is completed.

\subsubsection{Data Source}

a. The Study of the Literature and Research Data

The study of the literature was conducted to trace the various literature sourced from journals indexed Scopus (such as IEEE Xplore, ScienceDirect, Springer), a paper transaction, paper proceedings [1-45], and related documentation from previous research experts in their field. References collected materials for the determination of the foundation of the next steps in order to achieve the objectives of this research.

The study of the literature undertaken include things related characteristics of wind-based DG, test system distribution, mathematical modeling and methods of use of FPA functions [13] [14] to increase the reliability of the distribution system by minimising the ENS [10] [12]. Research data obtained from previous research data has been done [12].

The following is the data used in this study: 
The data in the form of the planning parameters the installation of wind-based DG in the distribution system. Data about the economic problems of planning parameters are shown in Table 3.1 the following [12].

Table 3.1 The planning parameters of the economic problems [12]

\begin{tabular}{|l|l|l|l|}
\hline Parameters & Time Interval & Unit & Value \\
\hline $\mathrm{IC}_{\mathrm{DG}}$ & - & $\$ / \mathrm{kW}$ & 1.200 \\
\hline & & & \\
\hline $\mathrm{MC}_{\mathrm{DG}}$ & first 2 years & $\$ / \mathrm{kW}$ & 26,04 \\
\hline & Between year 3 and 10 & $\$ / \mathrm{kW}$ & 33,00 \\
\hline & Between year 11 and 20 & $\$ / \mathrm{kW}$ & 36,48 \\
\hline & & & \\
\hline $\mathrm{C}_{\mathrm{ENS}}$ & 30 minutes & $\$ / \mathrm{kWh}$ & 0,4 \\
\hline & 4 hours & $\$ / \mathrm{kWh}$ & 8 \\
\hline & & & \\
\hline $\mathrm{C}_{\mathrm{T}}$ & - & $\$ / \mathrm{kWh}$ & 0,1 \\
\hline$\alpha_{\mathrm{t}}$ & - & - & 1,05 \\
\hline $\mathrm{T}$ & - & year & 20 \\
\hline
\end{tabular}

Table 3.1 interpreting the value of the investment cost from wind-based DG is $\$ 1200 / \mathrm{kW}$. The greater capacity wind-based DG which installs, and more expensive cost of investment, so did the opposite. From the other side, the costs of maintenance of wind-based DG are fluctualive and tend to be dynamic. This caused the maintenance costs year after year that continues to increase. The first and second year of $\$ 26,04 / \mathrm{kW}$; between year 3 and $10 \$ 33.00 / \mathrm{kW}$; while the year 11 and 20 of $\$ 36,48 / \mathrm{kW}$.

By using the equation 2-17 then the value $r_{i}$ is 39 hours/year, the value of the ENS before installation windbased DG is 5,927.6 kWh [12]. The value $r_{i}$ i.e. 39 hours/year will be included in the MATLAB software for programming with the aim to find the index value the reliability of distribution system after the optimal placement of wind-based DG on a particular bus.

$\mathrm{C}_{\text {ENS }}$ value in this study was developed so that there is a difference with the existing research, in research [12] value $C_{\text {ENS }}$ set $\$ 0.4 / \mathrm{kWh}$ and $\$ 8 / \mathrm{kWh}$, but in this study the value of $\mathrm{C}_{\mathrm{ENS}}$ vary, i.e. in the amount of: $\$ 0 / \mathrm{kWh}, \$ 8 / \mathrm{kWh}, \$ 20 / \mathrm{kWh}$, and $\$ 30 / \mathrm{kWh}$. The variation of the value of $\mathrm{C}_{\mathrm{ENS}}$ is the development of case studies. Here, the layout of the proposed development in this research.

\subsubsection{Cost Calculation Method}

How to calculate total costs in this study is as follows:

First, calculate the cost of the investment and maintenance costs of wind-based DG. Its mathematical formulation is expressed as follows:

Tribe 1 and tribe 2

In tribes 1 and 2 consist of the total cost of the investment and maintenance costs.

Total cost $(\mathrm{OF} 1)=$ investment cost + maintenance cost

$\mathrm{OF} 1=\sum_{\mathrm{i}=1}^{\mathrm{N}} \cdot\left(\mathrm{C}_{\mathrm{DG}} \cdot \mathrm{IC}_{\mathrm{DG}}\right)+\sum_{\mathrm{t}=1}^{\mathrm{T}} \cdot \alpha_{\mathrm{t}} \cdot\left(\sum_{\mathrm{i}=1}^{\mathrm{N}}\left(\mathrm{C}_{\mathrm{DGi}} \mathrm{MC} \mathrm{MC}_{\mathrm{DG}}\right)\right)$

After the tribes 1 and 2 count, then went on to the next step. Second, the cost of power loss is also calculated in this study. Its mathematical formulation is expressed as follows:

\section{Tribe 1, tribe 2, and tribe 3}

Total cost $(\mathrm{OF} 2)=$ investment cost + maintenance cost $+\mathrm{p}_{\text {loss }}$ cost

$\mathrm{OF} 2=\sum_{\mathrm{i}=1}^{\mathrm{N}} \cdot\left(\mathrm{C}_{\mathrm{DG}} \cdot \mathrm{IC}_{\mathrm{DG}}\right)+\sum_{\mathrm{t}=1}^{\mathrm{T}} \cdot \alpha_{\mathrm{t}} \cdot\left(\sum_{\mathrm{i}=1}^{\mathrm{N}}\left(\mathrm{C}_{\mathrm{DGi}} \mathrm{MC} \mathrm{MG}_{\mathrm{DG}}\right)\right)+\sum_{\mathrm{t}=1}^{\mathrm{T}} \cdot \alpha_{\mathrm{t}} \cdot\left(\mathrm{P}_{\text {loss }} \mathrm{C}_{\mathrm{T}}\right) \cdot 8760$

After the tribe of 1 to 3 are counted could get in on the last calculation. Third, the cost of the ENS were also taken into account in this study. Its mathematical formulation is expressed as follows:

Tribe 1, tribe 2, tribe 3, and tribe 4

Total cost $(\mathrm{OF} 3)=$ investment cost + maintenance cost $+\mathrm{p}_{\text {loss }} \cos \mathrm{t}+\mathrm{ENS}_{\mathrm{E}} \cos \mathrm{t}$ 
$\mathrm{OF} 3=\sum_{\mathrm{i}=1}^{\mathrm{N}} \cdot\left(\mathrm{C}_{\mathrm{DG}} \mathrm{IC}_{\mathrm{DG}}\right)+\sum_{\mathrm{t}=1}^{\mathrm{T}} \cdot \alpha_{\mathrm{t}} \cdot\left(\sum_{\mathrm{i}=1}^{\mathrm{N}}\left(\mathrm{C}_{\mathrm{DGi}} \cdot \mathrm{MC}_{\mathrm{DG}}\right)\right)+\sum_{\mathrm{t}=1}^{\mathrm{T}} \cdot \alpha_{\mathrm{t}} \cdot\left(\mathrm{P}_{\text {loss. }} \mathrm{C}_{\mathrm{T}}\right) \cdot 8760+\sum_{\mathrm{t}=1}^{\mathrm{T}} \cdot \alpha_{\mathrm{t}} \cdot \operatorname{ENS} \cdot \mathrm{C}_{\mathrm{ENS}}(3-3)$

After all the aggregated, then the calculation is complete. The sum of all the tribes give meaning that total cost includes the cost of the investment, the maintenance costs, the cost of power loss, and energy not supplied cost which are not supplied have been calculated by systematically.

\subsubsection{Flowchart of FPA Method}

Flowchart FPA method shown in Figure 3.1.

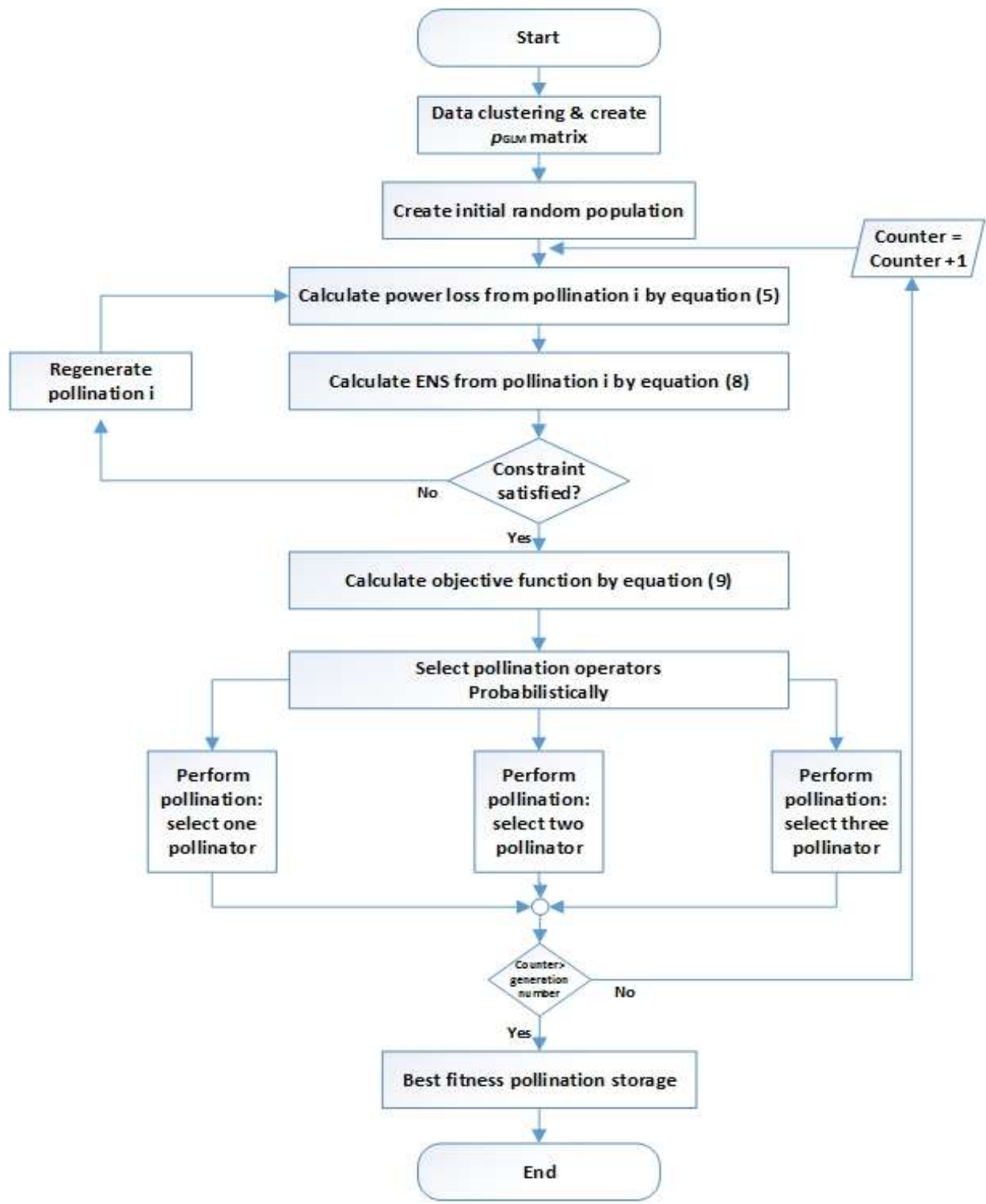

Figure 3.1 Flowchart of proposed method

After the analysis of the results and comparison, the last step is the preparation of the reports and conclusions of withdrawal research. The conclusion obtained from the analysis of the results is done. Preparation of research reports carried out by following the procedures in order to be easily understood. Following the steps of completion of studies by referring to the flowchart is proposed.

\section{Start}

Start having a meaning the start of the process of running a program using MATLAB software.

\section{Data clustering}

Data clustering is carried out by a systematic way so that the formed matrix $2 \times 2,2 \times 4$, and $2 \times 6$ for candidate placement and capacity.

\section{Create a random population of initials}


The initials of the population conducted randomly due to the method of FPA in its default program is indeed in-setting by making the initial random population. So, as a method of distinguishing things GA. Is in the method name individual FPA is the pollinator, while in the method name is the individual GA chromosome.

\section{Calculate of power loss}

Before calculate the power loss, the systematic steps need to do is calculate the power flow. The following is the flow diagram for calculating the flow of power so as to minimise the power loss. Flowchart shown in Figure 3.2 the following.

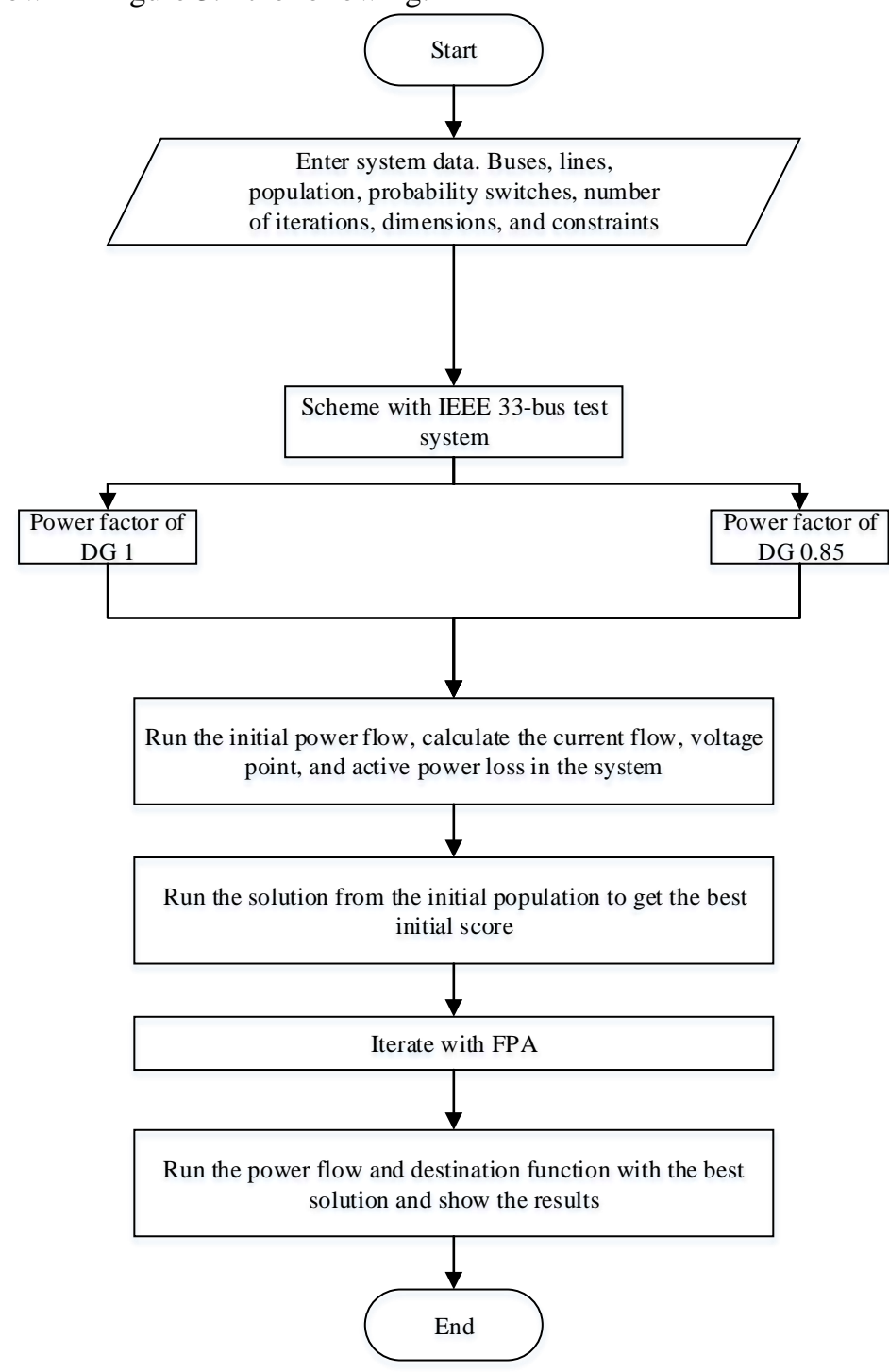

Figure 3.2 Flowchart of power flow

Power loss is calculated using equation (2-14). The result of the calculated power loss to prove that after the placement of wind-based DG, reduction of power more be smaller than the power loss prior to the placement of wind-based DG. Smaller power loss will affect the level of losses that is commonly referred to as the cost of power loss.

\section{Calculate of ENS index}

The calculation of the index is performed with ENS also take advantage the following equation: ENS $=$ Lavg.Ui

After the ENS index obtained then the next step is to confirm the restraints that have been set.

\section{Fulfilled constraints}

Constraints will be fulfilled if the purpose of entry function within the constraints that have been determined. Costraints in this research is the voltage profile, potential place of installation and operation of wind-based DG, namely bus 2 to bus 33, prospective capacity from wind-based DG which ranged between $56 \mathrm{~kW}$ up to $4,500 \mathrm{~kW}$, etc. 


\section{Calculate objective function}

The objective function is calculated using the equation (2-22). Objective function in this research is the total cost of the investment, maintenance, power loss, and ENS. Determination of total costs beginning with calculating power loss and ENS, by minimising the following functions:

$\min f(E N S)$ in order to increase reliability.

$\min f$ (losses) in order to reduction power loss.

In other words, the calculated cost related ENS and losses actually is a component of the cost advantages (benefits) that would be obtained if the wind-based DG installed in distribution systems. Instead, the calculated cost related investments and maintenance costs of a component that must be sacrificed (sacrifices) in advance if wish to profit from installaton wind-based DG in the distribution system.

\section{Choose best pollinator}

In the description below 1 pollinator, related to pollinator and 2 is an example for a single DG, with $2 \times 2$ matrix.

Pollinator $1=$ location. Equivalent of this function in the FPA is $\mathrm{Lb}=2$ and $\mathrm{Ub}=33$.

Pollinator 2 = capacity. Equivaent of this function $\mathrm{ib}$ the FPA is $\mathrm{Lb}=56$ and $\mathrm{Ub}=4,500$.

Equivalent function FPA for pollinator 1 means that the candidate's placement of wind-based DG is located between the bus by bus 2 to 33. Moreover, the equivalent function of the FPA to pollinator means that the candidate 2 capacity wind-based DG ranged between $56 \mathrm{~kW}$ up to $4,500 \mathrm{~kW}$.

Pollinators of selected by utilising method of FPA is the two best pollinators of the existing population. The acquisition of the best pollinators obtained through various processes as shown Figure 2.1 .

\section{Coding of initial population}

The following is the initial population of coding FPA method:

$\mathrm{X}_{\mathrm{i}}=$ population

Variable $1\left(\mathrm{~V}_{1}\right)=$ the prospective candidate location

Variabel $2\left(\mathrm{~V}_{2}\right)=$ the prospective candidate capacity

$V_{1}=\left[\frac{2,3,4,5,6,7,8,9,10,11,12,13,1415,1,17,18,19,20,21,22,23,24,25,26,27, \ldots, 33}{56,44 ; 160,19 ; 291,48 ; 420,41 ; 551,38 ; 701,7 ; \ldots ; 4.500}\right]$

$V_{2}=\left[\frac{2,3,4,5,6,7,8,9,10,11,12,13,1415,1,17,18,19,20,21,22,23,24,25,26,27, \ldots, \ldots, 33}{56,44: 160,19 \cdot 291,48 \cdot 420,41 \cdot 551,38 \cdot 701,7 \cdot \ldots \cdot 4.500}\right]$

\section{Minimise OF 1:}

Minimise $\mathrm{f}(\mathrm{x})=\mathrm{xi}_{1}$

Minimise $\mathrm{f}(\mathrm{x})=$ power loss

Minimise OF 2:

Minimise $\mathrm{f}(\mathrm{x})=\mathrm{xi}_{2}$

Minimise $\mathrm{f}(\mathrm{x})=$ energy not supplied

The next step:

Create a random initial population. Just like the algorithms inspired from nature more, FPA has the initials of the population which consists of 20 pieces. Solutions are generated at random but not all are created equal in an undemocratic society form; that will be assessed as a function of fitness. In this study a coding double feature of pollinators is proposed; on the first 33 bits refers to the candidates' buses (variable 1), and subsequent bits 33 refers to the capacity of wind-based DG (variable 2).

After that identify fitness (e.g. $g^{*}$ ) who becomes the best solution, then the identification of the probability value switch $P \mathcal{E}[0.1]$, these values have meaning probability switch between a local and a global pollination. When the conditions are less than a generation, the generation number for $i=1$ to $n$, if the random value is more than the population $(p)$ then enters on the operator's pollination.

\subsection{Pollination operator}

To implement operator pollination, 2 pieces selected as candidate pollinators and candidates from the capacity-based DG will be processed. In the next step, 2 pieces of these pollinators will be selected as the best pollinators because it has been through the stages of selection.

\subsection{Levy flight operator}


The next step is to move the vector $L$ on the distribution of the Levy, $L$ have dimension $d$. Here is an illustration motion Levy, shown in Figure 3.3 [13].

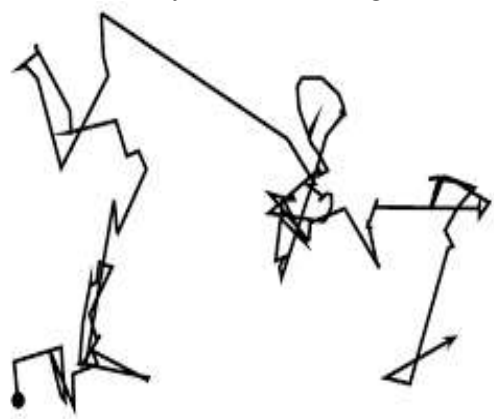

Figure 3.3 Levy flight

Apply global pollination with the following equation: $x_{i}^{t+1}=x_{i}^{t}+L\left(x_{i}^{t}-g^{*}\right)$, if it does not move $\varepsilon$ from the same distribution (uniform) on [0.1]. Then select the $j$ and $k$ at random among all solutions, then do pollination locally with the following mathematical equation: $x_{i}^{t+1}=x_{i}^{t}+\in\left(x_{j}^{t}-x_{k}^{t}\right)$, if done then calculate the fitness of the new solution. If the fitness of the new solution is better tham the old solution, then replace the old fitness solutions with new solution.

\section{Calculate number of generation}

Number generation is calculated in the following way. Numerical calculation with calculation so that it brings the best pollinators. Generally, through a variety of processes that are quite complex. A complex process that one counting the generations. Calculation of generation will generally cease when the value of the objective function has reached the best that have been optmised. The destination function (objective function) it must have fulfilled the function of the constraints. If the function has not met the objective function of the objective function, constraints will be exposed to a penalty. The search function of the goals will be carried out continuously until getting a goal function can fulfill the function of the constraints.

\section{Save the best fitness}

The value stored in memory of the best capabilities of the FPA. This algorithm is said to be smart because the algorithm pollination saves the best value. The value that is stored in the form of capabilities/best solution of existing problems.

10. End

Finish (end) is the end of the process flow diagram is proposed. The stage of completion indicates that the process is done by using the FPA method have already obtained the best solution.

\subsection{Observation Variable}

Variable observation in this study consists of three variables, namely the free variable (independent variable), variable control, and bound variable (dependent variable). Each variable will be observed and analysed.

Free variable is a variable whose value may vary and affect or be the cause of a change or the incidence of variables are bound. Free variables in this study is a data P (load) in the distribution system because of the disorder and not affected by the disorder.

The control variable is a variable whose value has been determined by researchers and not changed. Research on the control variables are the data mentioned in the previous chapter i.e. $U$ (unavailability). $U$ are the types of disorders and disorders of the old distribution system thus causing no tersuplainya electrical energy to the load.

Bound variable is output or the results of an experiment depends on the value of the variable input that is variable and variable control. Varibel attached to this research is the ENS or energy that is not supplied due to the onset of the disorder on the channel. The observed variable is the ENS index after placement of wind-based DG.

\subsection{Research Data}

\section{RESULTS \& DISCUSSION}

The data are processed in this secondary data research. The data required to run the load point of the research in active power $(\mathrm{P})$ data points, lines, line length used to define IEEE 33-bus test system into a form of computing [41], [42], failure rate rapidly per km per year $0.04 \mathrm{f} / \mathrm{km}$ yr [12], the duration of the repair for 4 hours 
[12]. The voltage level on the test system uses the base voltage level $12.66 \mathrm{kV}$ [43] so that it can be compared to other research. To test the system using IEEE 33-bus test system Figure 4.1 shows the following distribution system used in this study.

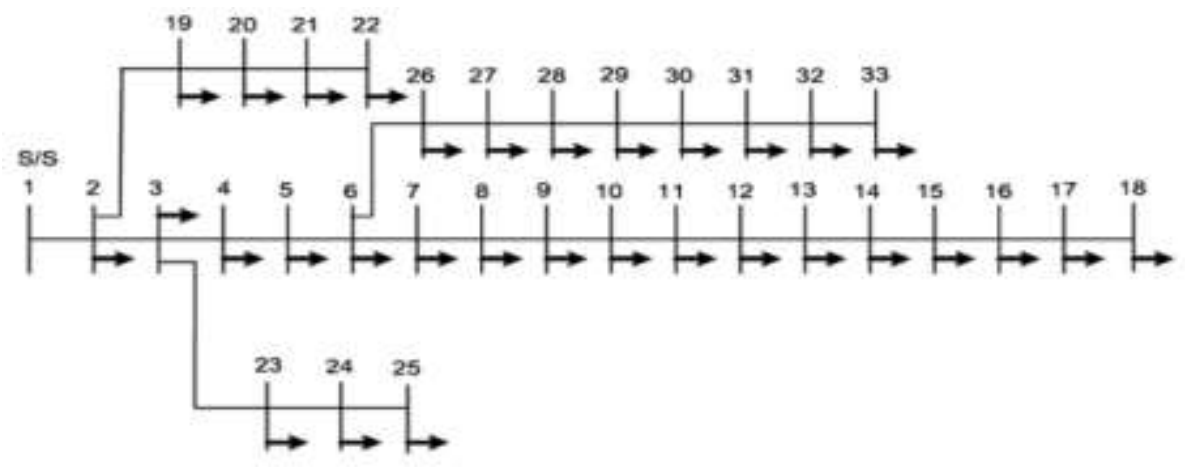

Figure 4.1 IEEE 33-bus test system

In the distribution system above interpret in a system consisting of 33 buses and comprises 33 branchs. On each bus has a load. The load on the IEEE 33-bus test system consist of 32 loads with a total load of 3,715 kW. The greatest burden lies in bus 24 and 25, each bus has a load of $420 \mathrm{~kW}$, while the smallest burden lies in the bus 12 to the value of the load on the bus are $42 \mathrm{~kW}$.

\subsection{Minimisation of ENS}

Case studies that were raised in this research is in the area of Lootak, Iran with average wind speeds range between $6.9 \mathrm{~m} / \mathrm{s}$ and the assumed distribution system there uses IEEE 33-bus test system. In this case study, the value of peak loads is 3.7 MW and 2.3 MVAR. Bus 1 is assumed as main substation [12]. For minimisastion study on ENS utilises the method of FPA. The method used for FPA put wind-based DG on placement in the proper bus so that ENS index can decrease.

Then about the cost of power loss and ENS cost are aso accounted in this study. The greater value of the power loss and loss cost then the ENS is getting bigger, so did the opposite.

Minimisation result $\mathrm{P}_{\text {loss }}$ and ENS with FPA method in this research is as follows.

Table 4.1 Research result

\begin{tabular}{|l|l|l|l|l|l|}
\hline \multirow{2}{*}{$\begin{array}{l}\text { Optimal } \\
\text { location }\end{array}$} & $\begin{array}{l}\text { Capacity } \\
(\mathrm{kW})\end{array}$ & \multicolumn{2}{|l|}{ Without DG } & \multicolumn{2}{l|}{ With DG } \\
\cline { 2 - 6 } & $\begin{array}{l}\text { Power loss } \\
(\mathrm{kW})\end{array}$ & ENS (kWh) & $\begin{array}{l}\text { Power loss } \\
(\mathrm{kW})\end{array}$ & ENS (kWh) \\
\hline 18 & 152.44 & 201.89 & $5,827.6$ & 80.77 & $4,294.0$ \\
14 & 305.02 & & & & \\
31 & 563.85 & & & & \\
\hline
\end{tabular}

An increase in reliability in the distribution system. Incresed reliability is characterised by a decline in ENS index after placement of wind-based DG in the distribution system. Before the placement of wind-based DG index of ENS worth 5,827.6 kWh. The value of initial $P_{\text {loss }}$ is 201.89 and the initial value of ENS index is $5,827.6 \mathrm{kWh}$. After the placement of wind-based DG on bus 18, 14, and 31 with a capacity $152.44 \mathrm{~kW}, 305.02$ $\mathrm{kW}$, and $53.85 \mathrm{~kW}$ then the ENS index decresed to 4,294.0 kWh. Comparation of the result for ENS and power loss minimisation, power factor (PF) value, namely 0.85 and $\mathrm{IC}_{\mathrm{DG}}$ worth $\$ 1,200 / \mathrm{kW}$ as well as $\mathrm{C}_{\mathrm{ENS}}$ worth $\$ 8 / \mathrm{kWh}$. The ENS index value of the decline occurred after the placement of wind-based DG. Wind-based DG positive effect against the reliability in the distribution system, thereby increasing reliability. In this study the time placement of wind-based DG, it is assumed that the frequency, voltage, and phase angle of wind-based DG has been in accordance with the frequency, voltage, and phase angle in the distribution system.

The difference in results between ENS index method which has been done by researchers using genetic algorithm previously (GA) with the method proposed by researcher using flower pollination algorithm (FPA) significant value. The results proved that the method of FPA has better performance in solving case studies.

The percentage decline in the index of ENS by using GA method is of $16.56 \%$; While the percentage decline in the index ENS using FPA utilises multi DG is $26.31 \%$. Refer to the percentage that has been calculated, there was a relatively significant margin difference between methods that have been used and the method proposed in 
the settlement of this case study. In this case study, it is evident that FPA method more effective than the GA method.

\subsection{Advanced Discussion}

\subsubsection{The Calculation of the Total Cost with the Variation of Ecnomics Parameter Values with Single DG}

The following Table 4.4 is the result of research on the total cost of which includes the cost of investment, the maintenance cost, the cost of power loss, and the cost of ENS in the span 20 years.

Table 4.2 Result the total cost with the variation of economics parameter values 1 wind-based DG (WBDG)

\begin{tabular}{|l|l|l|l|l|l|l|l|}
\hline $\begin{array}{l}\text { IC } \\
(\$ / \mathrm{kW}\end{array}$ & $\begin{array}{l}\mathrm{C}_{\text {ENS }} \\
(\$ / \mathrm{kWh})\end{array}$ & Location & $\begin{array}{l}\text { Capacity } \\
(\mathrm{kW})\end{array}$ & $\begin{array}{l}\text { Total of } \\
\text { WBDG }\end{array}$ & $\begin{array}{l}\text { ENS } \\
(\mathrm{kWh})\end{array}$ & $\begin{array}{l}\text { PL } \\
(\mathrm{kW})\end{array}$ & Total cost $(\$)$ \\
\hline 600 & 0 & 8 & $2,148.76$ & 1 & $2,433.3$ & 107.83 & $7,583,335.23$ \\
\hline 600 & 8 & 8 & $2,148.76$ & 1 & $2,433.3$ & 107.83 & $7,993,813.11$ \\
\hline 600 & 20 & 8 & $2,148.76$ & 1 & $2,433.3$ & 107.83 & $8,609,529.93$ \\
\hline 600 & 30 & 8 & $2,148.76$ & 1 & $2,433.3$ & 107.83 & $9,122,627.28$ \\
\hline 1,200 & 0 & 8 & $2,148.76$ & 1 & $2,433.3$ & 107.83 & $8,872,596.49$ \\
\hline 1,200 & 8 & 8 & $2,148.76$ & 1 & $2,433.3$ & 107.83 & $9,283,074.37$ \\
\hline 1,200 & 20 & 8 & $2,148.76$ & 1 & $2,433.3$ & 107.83 & $9,898,791.20$ \\
\hline 1,200 & 30 & 8 & $2,148.76$ & 1 & $2,433.3$ & 107.83 & $10,411,888.55$ \\
\hline 1,800 & 0 & 8 & $2,148.76$ & 1 & $2,433.3$ & 107.83 & $10,161,857.76$ \\
\hline 1,800 & 8 & 8 & $2,148.76$ & 1 & $2,433.3$ & 107.83 & $10,572,335.64$ \\
\hline 1,800 & 20 & 8 & $2,148.76$ & 1 & $2,433.3$ & 107.83 & $11,188,052.46$ \\
\hline 1,800 & 30 & 8 & $2,148.76$ & 1 & $2,433.3$ & 107.83 & $11,701,149.81$ \\
\hline 2,400 & 0 & 8 & $2,148.76$ & 1 & $2,433.3$ & 107.83 & $11,451,119.02$ \\
\hline 2,400 & 8 & 8 & $2,148.76$ & 1 & $2,433.3$ & 107.83 & $11,861,596.90$ \\
\hline 2,400 & 20 & 8 & $2,148.76$ & 1 & $2,433.3$ & 107.83 & $12,477,313.72$ \\
\hline 2,400 & 30 & 8 & $2,148.76$ & 1 & $2,433.3$ & 107.83 & $12,990,411.07$ \\
\hline
\end{tabular}

The value of $\mathrm{C}_{\mathrm{T}}, \alpha_{\mathrm{t}}, \mathrm{MC}_{\mathrm{DG}}$ set value constant and dynamic following Table 3.1 (in research), with PF value 1 [45], whereas the value of $C_{\text {ENS }}$ vary i.e. ranged from $\$ 0 / \mathrm{kWh}, \$ 8 / \mathrm{kWh}[12], \$ 20 / \mathrm{kWh}$, and $\$ 30 / \mathrm{kWh}$. On the basis of case studies, the condition of the investment cost of the WBDG is worth $\$ 1,200 / \mathrm{kW}$; the cost of maintenance is worth $\$ 26.04 / \mathrm{kW}$ for the first 2 years, $\$ 33.00 / \mathrm{kW}$ for years 3 to 10 years, and $\$ 36.48 / \mathrm{kW}$ for the $11^{\text {th }}$ year to $20^{\text {th }}$ year, WBDG worth $2.1 \mathrm{MW}$ capacity; the location of the WBDG is located in bus 8 causing the occurrence of guardian reliability and decreasing power loss in the distribution system.

The total cost of the cheapest covering the cost of the investment, the maintenance costs, the cost of power loss, and expense investment fee conditions with ENS $\$ 600 / \mathrm{kW}$ and the cost of interruptions due to the energy not suppiled that is worth $\$ 0 / \mathrm{kWh}$ in this case study is for $\$ 7,583,335.23$. The value of the cost of interruptions due to the energy not supplied that is worth $\$ 0 / \mathrm{kWh}$ the meaning is burden that affected due to the occurrence of ENS not suffered losses, as e.g. the burden in the form of housing. The value of the cost of energy not supplied ( $\mathrm{C}_{\mathrm{ENS}}$ ) varies due to different loads, at $\mathrm{C}_{\mathrm{ENS}}$ valued of $\$ 0 / \mathrm{kWh}$ then the load is affected due to the ENS do not feel the slightest harm, whereas at the moment the $C_{\text {ENS }}$ valued $\$ 8 / \mathrm{kWh} / \mathrm{kWh}, \$ 20$, and $\$ 30 / \mathrm{kWh}$ then the load is affected due to the ENS will feel the loss, for example the industry on a small scale, medium, and large. Total cost includes the cost of the investment, the maintenance costs, the cost of power loss, and expense investment fee conditions with ENS $\$ 1200 / \mathrm{kW}$ and the cost of interruptions due to the energy that is not supplied is worth $\$ 30 / \mathrm{kWh}$ in this case study is of $\$ 10,411,888.55$.

The value of the cost of interruptions due to the energy that is not supplied is worth $\$ 30 / \mathrm{kWh}$ the meaning is burden that affected due to the occurrence of ENS suffered heavy losses e.g. industrial steel mills, the factories suffered heavy losses due to the ENS because the factory could not produce steel in a certain span of time during the onset of the disorder. The smaller the cost investment WBDG then total cost of installation of the WBDG is getting smaller, and vice versa. Review of economy, large-scale industry most feel the impact loss due to ENS and benefit in the event of an increase in reliability.

In order to validate the results of the research, repeated optimisation of the total cost objective function of the 33-bus test system with the FPA method was obtained for robust and consistent results. In scenario 1 WBDG is done 10 (ten) times repeated optimisation to see the difference of given result. Number of iterations given as many as 1,000 iterations with a population of 20 in each iteration with a probability value of 0.8 and the number of wind-based DG a point. The following is the validation result of the FPA method for single DG shown in Table 4.3. 
Table 4.3 The rate of recurrence optimisation function purpose total cost on the system bus with 33-test FPA method for single DG

\begin{tabular}{|c|c|c|c|c|}
\hline & \multicolumn{4}{|c|}{ IEEE 33-bus test system } \\
\hline $\begin{array}{c}\text { Simulation } \\
\text { to- }\end{array}$ & $\begin{array}{c}\text { Number of iterations } \\
\text { until convergent }\end{array}$ & $\begin{array}{c}\text { Optimal } \\
\text { bus }\end{array}$ & $\begin{array}{c}\text { Optimal capacity } \\
(\mathrm{kW})\end{array}$ & Total cost (\$) \\
\hline 1 & 175 & 8 & $2,148.76$ & $10,411,888.55$ \\
\hline 2 & 250 & 8 & $2,148.76$ & $10,411,888.55$ \\
\hline 3 & 230 & 8 & $2,148.76$ & $10,411,888.55$ \\
\hline 4 & 250 & 8 & $2,148.76$ & $10,411,888.55$ \\
\hline 5 & 220 & 8 & $2,148.76$ & $10,411,888.55$ \\
\hline 6 & 175 & 8 & $2,148.76$ & $10,411,888.55$ \\
\hline 7 & 280 & 8 & $2,148.76$ & $10,411,888.55$ \\
\hline 8 & 250 & 8 & $2,148.76$ & $10,411,888.55$ \\
\hline 9 & 325 & 8 & $2,148.76$ & $10,411,888.55$ \\
\hline 10 & 120 & 8 & $2,148.76$ & $10,411,888.55$ \\
\hline Mean & 227.5 & 8 & $2,148.76$ & $10,411,888.55$ \\
\hline Std Dev & 58.60 & 0 & 0 & 0 \\
\hline
\end{tabular}

Table 4.5 shows the optimum convergence rate with the FPA method to minimise the total cost objective function on the 33-bus test system. It can be seen that the average number of iterations needed to achieve a convergent value of 227.5 iterations with a standard deviation of 58.60. Judging from the optimisation results, placement and DG capacity in 10 times running the simulation gives consistent results. This shows that the optimisation results of placement and capacity of WBDG on 33-bus test system with FPA method give convergent result.

The novelty in this research is the proposed method that the FPA method has better performance than the method used before. In terms of total cost, ENS, and power loss results, the three components are consistent and varied due to variations in the value of economic parameters and the proper placement and capacity of the WBDG. This research is expected to contribute to science in general, and its contribution to the science of electrical engineering in particular.

\subsubsection{Calculation of Total Cost with Variation of Value of Economics Parameter with Multi DG}

The following table shows the total cost of investment costs, maintenance costs, power loss costs, and ENS costs over a 20-year period for multi wind-based DG (2 WBDG).

Table 4.4 Result the total cost with the variation of economics parameter values 2 WBDG

\begin{tabular}{|l|l|l|l|l|l|l|l|}
\hline $\begin{array}{l}\text { IC } \\
(\$ / \mathrm{kW})\end{array}$ & $\begin{array}{l}\mathrm{C}_{\text {ENS }} \\
(\$ / \mathrm{kWh})\end{array}$ & Location & $\begin{array}{l}\text { Capacity } \\
(\mathrm{kW})\end{array}$ & $\begin{array}{l}\text { Total of } \\
\text { WBDG }\end{array}$ & $\begin{array}{l}\text { ENS } \\
(\mathrm{kWh})\end{array}$ & $\begin{array}{l}\text { PL } \\
(\mathrm{kW})\end{array}$ & Total cost $(\$)$ \\
\hline 600 & 0 & 32 & 572.82 & 2 & $4,227.5$ & 109.57 & $3,336,482.65$ \\
& & 16 & 431.66 & & & & \\
\hline 600 & 8 & 32 & 572.15 & 2 & $4,226.6$ & 109.50 & $4,046,849.35$ \\
& & 16 & 433.49 & & & & \\
\hline 600 & 20 & 14 & 602.76 & 2 & $3,739.5$ & 95.36 & $5,057,819.90$ \\
& & 31 & 715.17 & & & & \\
\hline 600 & 30 & 30 & 982.59 & 2 & $3,163.7$ & 86.01 & $5,791,044.34$ \\
& & 14 & 696.47 & & & & \\
\hline 1,200 & 0 & 32 & 583.58 & 2 & $4,185.8$ & 111.00 & $3,928,913.78$ \\
& & 17 & 401.74 & & & & \\
\hline 1,200 & 8 & 32 & 583.58 & 2 & $4,280.9$ & 111.00 & $4,644,308.91$ \\
& & 17 & 401.75 & & & & \\
\hline 1,200 & 20 & 32 & 572.83 & 2 & $4,227.5$ & 109.56 & $5,715,105.17$ \\
& & 16 & 431.66 & & & & \\
\hline 1,200 & 30 & 15 & 493.32 & 2 & $4,136.3$ & 106.37 & $6,599,356.79$ \\
& & 32 & 570.18 & & & & \\
\hline
\end{tabular}




\begin{tabular}{|c|c|c|c|c|c|c|c|}
\hline $1 \cap n$ & \multicolumn{7}{|c|}{$\begin{array}{l}n \\
\text { Table 4.4 Result the total cost with the variation of economics parameter values } 2 \text { WBDG (cont'd) }\end{array}$} \\
\hline 1,800 & 8 & $\begin{array}{l}32 \\
17 \\
\end{array}$ & $\begin{array}{l}583.59 \\
401.80\end{array}$ & 2 & $4,258.2$ & 111.00 & $5,235,589.07$ \\
\hline 1,800 & 20 & $\begin{array}{l}17 \\
32\end{array}$ & $\begin{array}{l}401.74 \\
583.58\end{array}$ & 2 & $4,271.1$ & 111.00 & $6,308,596.80$ \\
\hline 1,800 & 30 & $\begin{array}{l}17 \\
32\end{array}$ & $\begin{array}{l}401.74 \\
583.60\end{array}$ & 2 & $4,238.8$ & 111.00 & $7,202,843.20$ \\
\hline 2,400 & 0 & $\begin{array}{l}17 \\
32\end{array}$ & $\begin{array}{l}401.74 \\
583.58\end{array}$ & 2 & $4,258.4$ & 111.00 & $5,111,306.83$ \\
\hline 2,400 & 8 & $\begin{array}{l}32 \\
17 \\
\end{array}$ & $\begin{array}{l}583.57 \\
401.75 \\
\end{array}$ & 2 & $4,256.3$ & 111.00 & $5,826,707.89$ \\
\hline 2,400 & 20 & $\begin{array}{l}32 \\
17\end{array}$ & $\begin{array}{l}583.64 \\
401.73 \\
\end{array}$ & 2 & $3,491.8$ & 111.00 & $6,899,855.27$ \\
\hline 2,400 & 30 & $\begin{array}{l}32 \\
17 \\
\end{array}$ & $\begin{array}{l}583.58 \\
401.75 \\
\end{array}$ & 2 & $4,258.2$ & 111.00 & $7,794,050.34$ \\
\hline
\end{tabular}

The value of $\mathrm{C}_{\mathrm{T}}, \alpha_{\mathrm{t}}, \mathrm{MC}_{\mathrm{DG}}$ is set constantly and dynamically follows Table 3.1 (in research), with PF being 1 , while $\mathrm{C}_{\mathrm{ENS}}$ values vary between ranges $\$ 0 / \mathrm{kWh}, \$ 8 / \mathrm{kWh}, \$ 20 / \mathrm{kWh}$, and $\$ 30 / \mathrm{kWh}$. In a base case study, WBDG investment cost conditions are worth $\$ 1,200 / \mathrm{kW}$; maintenance costs worth $\$ 26.04 / \mathrm{kW}$ for the first 2 years, $\$ 33.00 / \mathrm{kW}$ for the $3^{\text {rd }}$ year until $10^{\text {th }}$ year, and $\$ 36.48 / \mathrm{kW}$ for the $11^{\text {th }}$ year until $20^{\text {th }}$ year. The investment value of wind-based DG is varied to $\$ 600 / \mathrm{kW}, \$ 1,200 / \mathrm{kW}, \$ 1,800 / \mathrm{kW}$, and $\$ 2,400 / \mathrm{kW}$ due to the types and specifications of wind-based DG generators, pole types, blade types, and so on. The cheapest total cost includes investment cost, maintenance cost, power loss cost and ENS cost with the investment cost of $\$ 600 / \mathrm{kW}$ and unpaid energy-related interruption cost of $\$ 0 / \mathrm{kWh}$ in this case study is $\$ 3,336,482.65$ with placement multi wind-based DG on 32 and 16 buses with a capacity of $572.82 \mathrm{~kW}$ and $431.66 \mathrm{~kW}$.

Total cost which includes investment cost, maintenance cost, power loss cost, and ENS cost with investment cost of $\$ 1,200 / \mathrm{kW}$ and unpaid energy cost of $\$ 30 / \mathrm{kWh}$ in this case study is $\$ 6,599,356.79$ with WBDG capacity worth $493.32 \mathrm{~kW}$ and $579.18 \mathrm{~kW}$; WBDG placement locations are located on buses 15 and 32 which lead to increased reliability and decreased power losses in the distribution system. The smaller the WBDG investment cost the greater the capacity of WBDG, and vice versa.

Viewed from the side of the economy, large-scale industry that is the industry that has a $\mathrm{C}_{\mathrm{ENS}}$ value of $\$ 30$ / $\mathrm{kWh}$ most feel the impact of losses due to large ENS, it is because when the ENS big industry can not produce products during a certain time and large-scale industry the real will not feel the loss if there is an increase in reliability, while the housing has a value of $\mathrm{C}_{\mathrm{ENS}} \$ 0 / \mathrm{kWh}$ not too feel the impact of losses due to ENS.

Sensitivity analysis is done by varying one or more factors, i.e. WBDG investment cost factor and uncompensated energy cost factor $\left(\mathrm{C}_{\mathrm{ENS}}\right)$, and maintenance cost factor from WBDG $\left(\mathrm{MC}_{\mathrm{DG}}\right)$, while other factors are made constant. The amount of the variables used as a basis in conducting sensitivity analysis is influenced by the price of electrical energy that varies depending on the activity needs of the load supplied.

In this case, the total cost of using single DG with multi DG (2 WBDG) is more advantageous using multi DG, it is the same parameter and case with single DG yields total cost of $\$ 10,411,888.55$, whereas with multi DG produce total cost of $\$ 6,599,356.79$.

In order to validate the results of the research, repeated optimisation of the total cost objective function of the 33-bus test system with the FPA method was obtained for robust and consistent results. In the $2^{\text {nd }}$ scenario WBDG is performed 10 (ten) times of repeated optimisation to see the difference in the results given. Number of iterations given as many as 2,000 iterations with a population of 20 in each iteration with a probability value of 0.8 and two DG wind-based points [45]. Here is the validation result of FPA method for multi DG shown in Table 4.5 . 
Table 4.5 The rate of recurrence optimisation function purpose total cost on the system bus with 33-test FPA method for 2 WBDG

\begin{tabular}{|c|c|c|c|c|}
\hline \multirow[b]{2}{*}{$\begin{array}{l}\text { Simulation } \\
\text { to- }\end{array}$} & \multicolumn{4}{|c|}{ 33-bus test system } \\
\hline & $\begin{array}{c}\text { Number of iterations } \\
\text { until convergent }\end{array}$ & $\begin{array}{l}\text { Optimal } \\
\text { bus }\end{array}$ & $\begin{array}{c}\text { Optimal capacity } \\
(\mathrm{kW})\end{array}$ & Total cost $(\$)$ \\
\hline 1 & 325 & $\begin{array}{l}15 \\
32 \\
\end{array}$ & $\begin{array}{r}493.32 \\
570.18 \\
\end{array}$ & $6,599,356.79$ \\
\hline 2 & 330 & $\begin{array}{l}15 \\
32\end{array}$ & $\begin{array}{l}493.32 \\
570.18\end{array}$ & $6,599,356.79$ \\
\hline 4 & 220 & $\begin{array}{l}15 \\
32\end{array}$ & $\begin{array}{l}493.32 \\
570.18\end{array}$ & $6,599,356.79$ \\
\hline 5 & 325 & $\begin{array}{l}15 \\
32 \\
\end{array}$ & $\begin{array}{l}493.32 \\
570.18 \\
\end{array}$ & $6,599,356.79$ \\
\hline 6 & 360 & $\begin{array}{l}15 \\
32 \\
\end{array}$ & $\begin{array}{l}493.32 \\
570.18 \\
\end{array}$ & $6,599,356.79$ \\
\hline 7 & 280 & $\begin{array}{l}15 \\
32 \\
\end{array}$ & $\begin{array}{l}493.32 \\
570.18 \\
\end{array}$ & $6,599,356.79$ \\
\hline 8 & 230 & $\begin{array}{l}15 \\
32 \\
\end{array}$ & $\begin{array}{l}493.32 \\
570.18 \\
\end{array}$ & $6,599,356.79$ \\
\hline 9 & 260 & $\begin{array}{l}15 \\
32 \\
\end{array}$ & $\begin{array}{l}493.32 \\
570.18 \\
\end{array}$ & $6,599,356.79$ \\
\hline 10 & 150 & $\begin{array}{l}15 \\
32 \\
\end{array}$ & $\begin{array}{l}493.32 \\
570.18 \\
\end{array}$ & $6,599,356.79$ \\
\hline Mean & 286 & $\begin{array}{l}15 \\
32 \\
\end{array}$ & $\begin{array}{l}493.32 \\
570.18 \\
\end{array}$ & $6,599,356.79$ \\
\hline Std Dev & 71.48 & 0 & 0 & 0 \\
\hline
\end{tabular}

Table 4.5 shows the optimum convergence rate with the FPA method to minimise the total cost objective function on the 33-bus test system. It can be seen that the average number of iterations required to achieve a convergent value of 286 iterations with a standard deviation of 71.48. Judging from the optimisation results placement and capacity of WBDG in 10 times running the simulation gives consistent results. This shows that the optimisation results of placement and capacity of WBDG on 33-bus test system with FPA method give convergent result.

The following table summarises the total costs that include investment costs, maintenance costs, power loss costs, and ENS costs over a 20-year period for multi wind-based DG (3 WBDG).

Table 4.6 Result the total cost with the variation of economics parameter values 3 WBDG

\begin{tabular}{|c|c|c|c|c|c|c|c|}
\hline $\begin{array}{l}\mathrm{IC}_{\mathrm{DG}} \\
(\$ / \mathrm{kW})\end{array}$ & $\begin{array}{l}\mathrm{C}_{\text {ENS }} \\
(\$ / \mathrm{kWh})\end{array}$ & Location & $\begin{array}{l}\text { Capacity } \\
(\mathrm{kW})\end{array}$ & $\begin{array}{l}\text { Total of } \\
\text { WBDG }\end{array}$ & $\begin{array}{l}\text { ENS } \\
(\mathrm{kWh})\end{array}$ & $\begin{array}{l}\text { PL } \\
(\mathrm{kW})\end{array}$ & Total cost $(\$)$ \\
\hline 600 & 0 & $\begin{array}{l}32 \\
18 \\
15\end{array}$ & $\begin{array}{l}577.75 \\
172.71 \\
245.41\end{array}$ & 3 & $4,017.0$ & 109.65 & $3,326,631.15$ \\
\hline 600 & 8 & $\begin{array}{l}32 \\
17 \\
14\end{array}$ & $\begin{array}{l}559.92 \\
205.19 \\
261.40\end{array}$ & 3 & $4,176.6$ & 107.74 & $4,036,485.53$ \\
\hline 600 & 20 & $\begin{array}{l}17 \\
31 \\
13 \\
\end{array}$ & $\begin{array}{l}238.37 \\
709.44 \\
378.08\end{array}$ & 3 & $3,633.4$ & 94.35 & $5,044,569.29$ \\
\hline 600 & 30 & $\begin{array}{l}30 \\
25 \\
14\end{array}$ & $\begin{array}{l}940.26 \\
421.76 \\
674.44\end{array}$ & 3 & $2,860.4$ & 76.31 & $5,731,401.79$ \\
\hline 1,200 & 0 & $\begin{array}{l}32 \\
15 \\
18\end{array}$ & $\begin{array}{l}581.56 \\
206.11 \\
201.81 \\
\end{array}$ & 3 & $4,088.9$ & 110.09 & $3,920,051.65$ \\
\hline 1,200 & 8 & $\begin{array}{l}18 \\
15 \\
32\end{array}$ & $\begin{array}{l}216.99 \\
186.56 \\
582.98\end{array}$ & 3 & $4,260.4$ & 110.31 & $4,633,507.51$ \\
\hline
\end{tabular}




\begin{tabular}{|c|c|c|c|c|c|c|c|}
\hline & & $\begin{array}{l}32 \\
15\end{array}$ & $\begin{array}{l}578.15 \\
249.56\end{array}$ & & & & \\
\hline 1,200 & 30 & $\begin{array}{l}17 \\
14 \\
32\end{array}$ & $\begin{array}{l}204.23 \\
305.02 \\
563.85\end{array}$ & 3 & $4,113.8$ & 105.27 & $6,588,069.86$ \\
\hline 1,800 & 0 & $\begin{array}{l}32 \\
18 \\
15\end{array}$ & $\begin{array}{l}584.64 \\
230.12 \\
171.70\end{array}$ & 3 & $4,027.1$ & 110.36 & $4,511,119.78$ \\
\hline 1,800 & 8 & $\begin{array}{l}18 \\
32 \\
15\end{array}$ & $\begin{array}{l}222.18 \\
583.48 \\
179.96\end{array}$ & 3 & $4,260.0$ & 110.38 & $5,224,711.46$ \\
\hline 1,800 & 20 & $\begin{array}{l}18 \\
32 \\
15\end{array}$ & $\begin{array}{l}220.94 \\
583.90 \\
181.23\end{array}$ & 3 & $4,180.9$ & 110.35 & $6,298,015.94$ \\
\hline 1,800 & 30 & $\begin{array}{l}18 \\
15 \\
32\end{array}$ & $\begin{array}{l}225.32 \\
178.93 \\
584.67\end{array}$ & 3 & $4,248.5$ & 110.19 & $7,193,497.49$ \\
\hline 2,400 & 0 & $\begin{array}{l}32 \\
18 \\
15\end{array}$ & $\begin{array}{l}583.61 \\
222.05 \\
179.97\end{array}$ & 3 & $4,155.5$ & 110.38 & $5,100,795.78$ \\
\hline 2,400 & 8 & $\begin{array}{l}15 \\
17 \\
32\end{array}$ & $\begin{array}{l}126.69 \\
275.02 \\
584.69\end{array}$ & 3 & $4,247.5$ & 110.40 & $5,818,743.49$ \\
\hline 2,400 & 20 & $\begin{array}{l}32 \\
17 \\
15\end{array}$ & $\begin{array}{l}583.73 \\
291.94 \\
110.01\end{array}$ & 3 & $3,697.7$ & 110.48 & $6,891,155.94$ \\
\hline 2,400 & 30 & $\begin{array}{l}15 \\
32 \\
18\end{array}$ & $\begin{array}{l}179.80 \\
583.43 \\
222.61\end{array}$ & 3 & $4,198.8$ & 110.36 & $7,783,433.61$ \\
\hline
\end{tabular}

The value of $\mathrm{C}_{\mathrm{T}}, \alpha_{\mathrm{t}}, \mathrm{MC}_{\mathrm{DG}}$ is set constantly and dynamically following Table 3.1 (in research), with PF being 1 , while $C_{\text {ENS }}$ values vary between $\$ 0 / \mathrm{kWh}, \$ 8 / \mathrm{kWh}, \$ 20 / \mathrm{kWh}$, and $\$ 30 / \mathrm{kWh}$. At WBDG investment cost of $\$ 1,200 / \mathrm{kW}$; maintenance costs worth $\$ 26.04 / \mathrm{kW}$ for the first 2 years, $\$ 33.00 / \mathrm{kW}$ for the $3^{\text {rd }}$ year until $10^{\text {th }}$ year, and $\$ 36.48 / \mathrm{kW}$ for the $11^{\text {th }}$ year until $20^{\text {th }}$ year. The cheapest total cost includes investment costs, maintenance costs, power loss costs and ENS costs under the investment cost of $\$ 600 / \mathrm{kW}$ and unpaid energy-related interruptions costs $\$ 0 / \mathrm{kWh}$ in this case study of $\$ 3,326,631.15$ with DG multi wind-based placement on 32,18 , and 15 buses with a capacity of $577.75 \mathrm{~kW}, 172.71 \mathrm{~kW}$ and $245.41 \mathrm{~kW}$.

Total costs which include investment cost, maintenance cost, power loss cost, and ENS cost with investment cost of $\$ 1,200 / \mathrm{kW}$ and unpaid energy cost of $\$ 30 / \mathrm{kWh}$ in this case study were $\$ 6,588,069.86$ with WBDG capacity worth $204.23 \mathrm{~kW}, 305.02 \mathrm{~kW}$, and $563.85 \mathrm{~kW}$; the location of the WBDG is located on buses 17, 14, and 32 which leads to an increase in reliability and loss of power losses in the distribution system. The smaller the WBDG investment cost the greater the capacity of WBDG, and vice versa.

In terms of economics, large-scale industries, industries that have a $\mathrm{C}_{\mathrm{ENS}}$ value of $\$ 30 / \mathrm{kWh}$ most feel the impact of losses due to ENS, it is because when the ENS big industry can not produce its products during a certain timeframe during a blackout and industrial scale the great is true will not be overwritten if there is an increase in reliability that is supplied electrical energy in a sustainable or in other words there is a back-up of the WBDG when the interruption occurs so that production will still run normally, whereas in the housing that has a $\mathrm{C}_{\text {ENS }} \$ 0 / \mathrm{kWh}$ not too feel the impact of losses due to ENS, because generally the housing does not produce goods or services. On the other hand, there are also some countries, namely the PRC country and in Thailand which produce goods in small medium-sized enterprises (SMEs) in the housing industry.

The investment value of WBDG or IC $_{\mathrm{DG}}$ varies based on the type and specification of all components of WBDG that have different prices. The types and specifications of the medium-sized WBDG components are priced at $\$ 600 / \mathrm{kW}$. The types and specifications of good WBDG components are priced at $\$ 1,200 / \mathrm{kW}$. The types and specifications of the excellent WBDG components are priced at $\$ 1,800 / \mathrm{kW}$ and $\$ 2,400 / \mathrm{kW}$. Similarly, for variations in $\mathrm{C}_{\mathrm{ENS}}$ values, these variations are based on different loads such as loads on housing with $\mathrm{C}_{\mathrm{ENS}} \$ 0 / \mathrm{kWh}$, small-scale industry with $\mathrm{C}_{\mathrm{ENS}}$ value of $\$ 8 / \mathrm{kWh}$, medium-scale industry with $\mathrm{C}_{\mathrm{ENS}}$ value of $\$ 20 / \mathrm{kWh}$, and large-scale industry with a $\mathrm{C}_{\mathrm{ENS}}$ value of $\$ 30 / \mathrm{kWh}$.

To validate the results of the research, repeated optimisation of the total cost objective function, ENS, and active power losses on the 33-bus test system with the FPA method for robust and consistent results. In this 
scenario, 10 (ten) repeated optimisations are performed to see the difference in the given result. Number of iterations given as many as 4,000 iterations with a population of 20 in each iteration with a probability value of 0.8 and three DG wind-based points. Here is the validation result of FPA method for multi DG (3 WBDG) shown in Table 4.7 below.

Table 4.7 The rate of recurrence optimisation function purpose total cost on the system bus with 33-test FPA method for 3 WBDG

\begin{tabular}{|c|c|c|c|c|}
\hline & \multicolumn{4}{|c|}{ 33-bus test system } \\
\hline $\begin{array}{l}\text { Simulation } \\
\text { to- }\end{array}$ & $\begin{array}{c}\text { Number of iterations } \\
\text { until convergent }\end{array}$ & $\begin{array}{l}\text { Optimal } \\
\text { bus }\end{array}$ & $\begin{array}{c}\text { Optimal capacity } \\
(\mathrm{kW})\end{array}$ & Total cost $(\$)$ \\
\hline 1 & 270 & $\begin{array}{l}17 \\
14 \\
32\end{array}$ & $\begin{array}{l}204.23 \\
305.02 \\
563.85\end{array}$ & $6,588,069.86$ \\
\hline 2 & 235 & $\begin{array}{l}17 \\
14 \\
32\end{array}$ & $\begin{array}{l}204.23 \\
305.02 \\
563.85\end{array}$ & $6,588,069.86$ \\
\hline 3 & 260 & $\begin{array}{l}17 \\
14 \\
32\end{array}$ & $\begin{array}{l}204.23 \\
305.02 \\
563.85\end{array}$ & $6,588,069.86$ \\
\hline 4 & 290 & $\begin{array}{l}17 \\
14 \\
32\end{array}$ & $\begin{array}{l}204.23 \\
305.02 \\
563.85\end{array}$ & $6,588,069.86$ \\
\hline 5 & 345 & $\begin{array}{l}17 \\
14 \\
32\end{array}$ & $\begin{array}{l}204.23 \\
305.02 \\
563.85\end{array}$ & $6,588,069.86$ \\
\hline 6 & 140 & $\begin{array}{l}17 \\
14 \\
32 \\
\end{array}$ & $\begin{array}{l}204.23 \\
305.02 \\
563.85\end{array}$ & $6,588,069.86$ \\
\hline 7 & 340 & $\begin{array}{l}17 \\
14 \\
32 \\
\end{array}$ & $\begin{array}{l}204.23 \\
305.02 \\
563.85\end{array}$ & $6,588,069.86$ \\
\hline 8 & 290 & $\begin{array}{l}17 \\
14 \\
32 \\
\end{array}$ & $\begin{array}{l}204.23 \\
305.02 \\
563.85\end{array}$ & $6,588,069.86$ \\
\hline 9 & 340 & $\begin{array}{l}17 \\
14 \\
32 \\
\end{array}$ & $\begin{array}{l}204.23 \\
305.02 \\
563.85 \\
\end{array}$ & $6,588,069.86$ \\
\hline 10 & 360 & $\begin{array}{l}17 \\
14 \\
32 \\
\end{array}$ & $\begin{array}{l}204.23 \\
305.02 \\
563.85 \\
\end{array}$ & $6,588,069.86$ \\
\hline Mean & 287 & $\begin{array}{l}32 \\
17 \\
14 \\
\end{array}$ & $\begin{array}{l}204.23 \\
305.02 \\
563.85 \\
\end{array}$ & $6,588,069.86$ \\
\hline Std Dev & 66.38 & 0 & 0 & 0 \\
\hline
\end{tabular}

Table 4.7 shows the optimum convergence rate with the FPA method to minimise the total cost objective function on the 33-bus test system. It can be seen that the average number of iterations needed to achieve a convergent value of 287 iterations with a standard deviation of 66.38. Judging from the optimisation results placement and capacity of WBDG in 10 times running the simulation gives consistent results. This shows that the optimisation results of placement and capacity of WBDG on 33-bus test system with FPA method give convergent result.

The percentage decrease in the ENS index by using the GA method is $16.56 \%$; while the percentage decrease of ENS index by using FPA method using multi DG is equal to $26,31 \%$. The difference is $9.75 \%$. In this case the FPA method performs better.

In this case, the total cost of using single DG with multi DG is more advantageous using multi DG (3 WBDG), it is filed with parameters and the same case with single DG generates a total cost of $\$ 10,411,888.55$, a $\mathrm{P}_{\text {loss }}$ value of $107.83 \mathrm{~kW}$, and the ENS index of $2,433.3 \mathrm{kWh}$, whereas with multi DG (2 WBDG) yielded a total cost of $\$ 6,599,356.79$, Ploss value of $106.37 \mathrm{~kW}$, and an ENS index of 4,136.3 $\mathrm{kWh}$, while with multi DG 
(3 WBDG) generates a total cost of $\$ 6,588,069.86, \mathrm{P}_{\text {loss }}$ value of $105.27 \mathrm{~kW}$, and an ENS index of 4,113.8 $\mathrm{kWh}$.

\subsection{Conclusions}

\section{CONCLUSIONS \& RECOMMENDATIONS}

1. Increased reliability, decreased power loss, and improved voltage profile after wind-based DG placement in the distribution system on bus 8 with a capacity of $2.1 \mathrm{MW}$ for single DG, placement on bus 15 and 32 with a capacity of $493.32 \mathrm{~kW}$ and $570.18 \mathrm{~kW}$ for multi DG (2 WBDG), and placement on buses 17, 14, and 32 with capacities of $204.23 \mathrm{~kW}, 305.02 \mathrm{~kW}$, and $563.85 \mathrm{~kW}$ for multi DG (3 WBDG).

2. Total costs that include investment costs, maintenance costs, power loss costs, and ENS costs after installation of a DG wind-based on an existing IEEE 33-bus test system for 20 years are $\$ 10,411,888.55$ for single DG, \$ 6,599,356.79 for $2 \mathrm{WBDG}$, and \$6,588,069.86 for 3 WBDG (multi DG), installation of 3 WBDG is the right choice.

\subsection{Recommendations}

1. Further research, can use other methods either based on natural-inspired metaheuristic algorithms, stochastic approach, or robust optimisation techniques.

2. Further research, can use rupiah ( $R p)$ currency to be calculated planning related to investment cost, maintenance cost, cost of loss of power, and cost of ENS in rupiah currency to projection total cost for wind-based DG planning in Indonesia.

\section{REFERENCES}

[1] T. Power and S. Reliability, "RTD2004-66012," 2004.

[2] Y. M. Atwa, S. Member, S. Member, M. M. A. Salama, and R. Seethapathy, "Optimal Renewable Resources Mix for Distribution System Energy Loss Minimisation,” vol. 25, no. 1, pp. 360-370, 2010.

[3] Y. M. Atwa, S. Member, and S. Member, "Supply Adequacy Assessment of Distribution System Including Windbased DG During Different Modes of Operation," vol. 25, no. 1, pp. 78-86, 2010.

[4] G. Desrochers, M. Blanchard, and S. Sud, "A Monte-Carlo Simulation Method for the Economic Assessment of the Contribution of Wind Energy to Power Systems," IEEE Trans. Energy Convers., vol. EC-1, no. 4, pp. 50-56, 1986.

[5] M. C. Bozchalui, M. IEEE, R. Sharma, and M. IEEE, "Optimal Operation of Energy Storage in Distribution Systems with Renewable Energy Resources," no. 2.

[6] H. Chen and R. Billinton, "Generating Systems using Wind Energy," no. 97, pp. 47-52, 1997.

[7] A. B. Culaba, L. A. G. Lim, and A. H. P. Unit, "Design of Yaw B Brake System for Horizontal Axis Wind Turbine Generator," 2015.

[8] S. H. Jangamshetti, S. Member, V. G. Rau, and S. Member, "Normalised Power Curves as a Tool for Identification of Optimum Wind Turbine Generator Parameters," vol. 16, no. 3, pp. 283-288, 2001.

[9] G. Allan, I. Eromenko, M. Gilmartin, I. Kockar, and P. McGregor, "The Economics of Distributed Energy Generation: A Literature Review,” Renew. Sustain. Energy Rev., vol. 42, pp. 543-556, 2015.

[10] B. Sultana, M. W. Mustafa, U. Sultana, and A. Rauf, "Review on Reliability Improvement and Power Loss Reduction in Distribution System via Network Reconfiguration,” vol. 66, pp. 297-310, 2016.

[11] M. Stojkov and S. Nikoiovski, "Estimation of Electrical Energy Not Supplied in Reliability Analysis of Distribution Networks," no. 1, pp. 967-970, 2004.

[12] S. Hakimi, H. Afrakhte, and M. Jabbari, "Probabilistic Method for Optimal Placement of Wind-based Distributed Generation with Considering Reliability Improvement and Power Loss Reduction."

[13] X. S. Yang, "Flower Pollination Algorithm for Global Optimisation," 2013.

[14] X. S. Yang, M. Karamanoglu, and X. He, "Multi-objective Flower Algorithm for Optimisation," Procedia Comput. Sci., vol. 18, pp. 861-868, 2013.

[15] T. Ackermann, G. Andersson, and L. Söder, "Distributed Generation: A Definition," Electr. Power Syst. Res., vol. 57, no. 3, pp. 195-204, 2001.

[16] S. M. Shahidehpour, "Reliability Evaluation of a Three-area Power System," Electr. Power Syst. Res., vol. 10, no. 3, pp. 227-233, 1986.

[17] A. Koshti, "Reliability Evaluation of Distribution System Accounting Distributed Generation Using Functional Link Network," pp. 25-30, 2009.

[18] D. R. Joshi, S. Member, S. H. Jangamshetti, and S. Member, "A Novel Method to Estimate the O \& M Costs for the Financial Planning of the Wind Power Projects based on Wind Speed — A Case Study," vol. 25, no. 1, pp. 161$167,2010$.

[19] K. S. Rao and M. N. Rao, "Multiple Distributed Generator Allocation by Harmony Search Algorithm for Loss Reduction," Proc. - ICETEEEM 2012, Int. Conf. Emerg. Trends Electr. Eng. Energy Manag., pp. 59-64, 2012.

[20] M. H. Sulaiman, M. W. Mustafa, A. Azmi, O. Aliman, and S. R. A. Rahim, "Optimal Allocation and Sizing of Distributed Generation in Distribution System via Firefly Algorithm,” no. June, pp. 6-7, 2012. 
[21] K. Nadhir, D. Chabane, and B. Tarek, "Firefly Algorithm for Optimal Allocation and Sizing of Distributed Generation in Radial Distribution System for Loss Minimisation," 2013 Int. Conf. Control. Decis. Inf. Technol. CoDIT 2013, pp. 231-235, 2013.

[22] D. C. Vega, J. A. Marin, and R. T. Sanchez, "Pitch Angle Controllers Design for a Horizontal Axis Wind Turbine," 2015.

[23] L. Zhang, L. Ma, K. Li, S. Gan, J. Yan, and X. Xu, "NARX Models for Predicting Power Consumption of a Horizontal Axis Wind Turbine," pp. 2-6, 2016.

[24] A. Yadav, "Design, Development, and Fabrication of Horizontal Axis Wind Turbine,” pp. 0-3, 2016.

[25] M. T. Do, J. Sprooten, S. Clenet, and B. Robyns, "Influence of Wind Turbines on Power System Reliability through Probabilistic Studies," Innov. Smart Grid Technol. Conf. Eur. (ISGT Eur. 2010 IEEE PES, pp. 2-7, 2010.

[26] K. Rohrig and B. Lange, "Improvement of the Power System Reliability by Prediction of Wind Power Generation," 2007.

[27] R. Karki, S. Member, P. Hu, S. Member, R. Billinton, and L. Fellow, “A Simplified Wind Power Generation Model for Reliability Evaluation," vol. 21, no. 2, pp. 533-540, 2006.

[28] X. Han, M. Mu, W. Qin, and A. W. S. Model, "Reliability Assessment of Power System Containing Wind Farm based on Steady-state Power Flow," no. 3, pp. 756-760, 2010.

[29] G. Chen, J. Zhang, M. Zhu, N. Dai, and X. Cai, "Optimised Design for Multi-MW Wind Power Converter based on Efficiency and Reliability," 2014.

[30] S. L. Tokyo Institute of Technology, "Wind Power and Wind Turbines," Engineering. pp. 1-35, 2009.

[31] C. Ordoudis, P. Pinson, J. M. Morales González, and M. Zugno, "An Updated Version of the IEEE RTS 24-bus System for Electricity Market and Power System Operation Studies," Tech. Univ. Denmark, 2016.

[32] C. Darwin, "The Abominable Mystery: How Flowers Conquered the World," pp. 1-8, 2017

[33] M. Ingrouille, "Understanding Flowers and Flowering: An Integrated Approach," Ann. Bot., vol. 103, no. 1, pp. vivii, 2009.

[34] N. M. Waser, T. A. Naturalist, and N. May, "Flower Constancy: Definition, Cause, and Measurement," vol. 127, no. 5, pp. 593-603, 2007.

[35] I. Pavlyukevich, "Levy Flights, Non-local Search and Simulated Annealing," J. Comput. Phys., vol. 226, no. 2, pp. 1830-1844, 2007.

[36] A. K. Rajeevan, "Identification of Reliability of Wind Power Generation and its Mathematical Modeling," 2013.

[37] B. K. Subramanian, A. B. Attya, and T. Hartkopf, "Novel Wind Turbine Reliability Model-implementation to Estimate Wind Farms Capacity Credit," Proc. Int. Conf. Harmon. Qual. Power, ICHQP, pp. 97-101, 2014.

[38] R. W. Mosobi, "Modeling and Power Quality Analysis of Integrated Renewable Energy System,” pp. 0-5, 2014.

[39] W. G. Morsi, C. P. Diduch, and L. Chang, "A New Islanding Detection Approach Using Wavelet Packet Transform for Wind-based Distributed Generation,” pp. 495-500, 2010.

[40] Y. M. Atwa, S. Member, S. Member, R. Seethapathy, and M. A. Salama, "Effect of Wind-based DG Seasonality and Uncertainty on Distribution System Losses," pp. 1-6, 2008.

[41] Maiti, A. "Load Flow Analysis of Radial Distribution Network Using Linear Data Structure. Master of Technology in Department of Computer Science \& Engineering (with specialisation in Computer Science), 2013.

[42] A. Skoonpong and S. Sirisumrannukul, "Network Reconfiguration for Reliability Worth Enhancement in Distribution Systems by Simulated Annealing," $5^{\text {th }}$ Int. Conf. Electr. Eng. Comput. Telecommun. Inf. Technol. ECTI-CON 2008, vol. 2, pp. 937-940, 2008.

[43] S. Naik, G. Naik, D. K. Khatod, and M. P. Sharma, "Analytical Approach for Optimal Siting and Sizing of Distributed Generation in Radial Distribution Networks," no. July 2014, pp. 209-220, 2015.

[44] M. R. Ali, "Optimasi Penempatan dan Kapasitas Distributed Generation dengan Metode Flower Pollination Algorithm," Skripsi, UGM, 2015.

[45] D. B. Santoso, "Optimisasi Penempatan dan Kapasitas Wind-based Distributed Generation untuk Minimisasi Losses Menggunakan Flower Pollination Algorithm," Tesis, UGM, 2017.

[46] S. Shaddiq, D. B. Santoso, F. F. Alfarobi, Sarjiya \& S.P. Hadi, "Optimal Capacity and Placement of Distributed Generation using Metaheuristic Optimisation Algorithm to Reduce Power Losses in Bantul Distribution System, Yogyakarta”. In $20168^{\text {th }}$ International Conference on Information Technolog and Electrical Engineering (ICITEE) (pp. 1-5). IEEE, 2016.

[47] Z. A. A. Alyasseri, A. T. Khader, M. A. Al-Betar, Awadallah, M. A., \& Yang, X. S. "Variants of the Flower Pollination Algorithm: A Review". Nature-Inspired Algorithms and Applied Optimisation, 91- 118, 2018.

[48] M. Abdel-Basset, \& L. A. Shawky, "Flower Pollination Algorithm: A Comprehensive Review". Artificial Intelligence Review, 52(4), 2533-2557, 2019.

[49] T. Adithiyaa, D. Chandramohan, \& T. Sathis, "Flower Pollination Algorithm for the Optimisation of Stair Casting Parameter for the Preparation of AMC". Materials Today: Proceedings, 21, 882-886, 2020.

[50] H. Mohammadzadeh, \& F. S. Gharehchopogh, "A Novel Hybrid Whale Optimisation Algorithm with Flower Pollination Algorithm for Feature Selection: Case Study Email Spam Detection”. Computational Intelligence, 37(1), 176-209. 